\title{
CССТC-binding factor inhibits breast cancer cell proliferation and metastasis via inactivation of the nuclear factor-kappaB pathway
}

\author{
Jie Wu ${ }^{1, *}$, Peng-Chang Li ${ }^{1, *}$, Jun-Yi Pang ${ }^{2}$, Guo-You Liu ${ }^{3}$, Xue-Min Xie ${ }^{3}$, Jia-Yao Li ${ }^{1}$, \\ Yi-Cong Yin ${ }^{1}$, Jian-Hua Han ${ }^{1}$, Xiu-Zhi Guo ${ }^{1}$ and Ling Qiu ${ }^{1}$ \\ ${ }^{1}$ Department of Clinical Laboratory, Peking Union Medical College Hospital, Peking Union Medical College and Chinese \\ Academy of Medical Science, Beijing, 100730, China \\ ${ }^{2}$ Department of Pathology, Peking Union Medical College Hospital, Peking Union Medical College and Chinese Academy of \\ Medical Science, Beijing, 100730, China \\ ${ }^{3}$ State Key Laboratory of Medical Molecular Biology, Department of Biochemistry and Molecular Biology, Institute of Basic \\ Medical Sciences, Chinese Academy of Medical Sciences and Peking Union Medical College, Beijing, 100005, China \\ *These authors contributed equally to this work
}

Correspondence to: Ling Qiu, email: lingqiubj@aliyun.com

Keywords: CCCTC-binding factor, breast cancer, proliferation, metastasis, nuclear factor-kappaB

Received: December 01, $2016 \quad$ Accepted: June 18, $2017 \quad$ Published: July 04, 2017

Copyright: Wu et al. This is an open-access article distributed under the terms of the Creative Commons Attribution License 3.0 (CC BY 3.0), which permits unrestricted use, distribution, and reproduction in any medium, provided the original author and source are credited.

\section{ABSTRACT}

CCCTC-binding factor (CTCF) is an important epigenetic regulator implicated in multiple cellular processes, including growth, proliferation, differentiation, and apoptosis. Although CTCF deletion or mutation has been associated with human breast cancer, the role of CTCF in breast cancer is questionable. We investigated the biological functions of CTCF in breast cancer and the underlying mechanism. The results showed that CTCF expression in human breast cancer cells and tissues was significantly lower than that in normal breast cells and tissues. In addition, CTCF expression correlated significantly with cancer stage $(P=0.043)$ and pathological differentiation $(P=\mathbf{0 . 0 2 9})$. Furthermore, CTCF overexpression resulted in the inhibition of proliferation, migration, and invasion, while CTCF knockdown induced these processes in breast cancer cells. Transcriptome analysis and further experimental confirmation in MDA-MD-231 cells revealed that forced overexpression of CTCF might attenuate the DNA-binding ability of nuclear factor-kappaB (NF-KB) p65 subunit and inhibit activation of NF-KB and its target pro-oncogenes (tumor necrosis factor alpha-induced protein 3 [TNFAIP3]) and genes for growth-related proteins (early growth response protein 1 [EGR1] and growth arrest and DNAdamage-inducible alpha [GADD45a]). The present study provides a new insight into the tumor suppressor roles of CTCF in breast cancer development and suggests that the CTCF/NF-KB pathway is a potential target for breast cancer therapy.

\section{INTRODUCTION}

Breast cancer continues to be the most common malignant tumor in women worldwide, with an estimated $25 \%$ of new cancer cases diagnosed [1-4]. Understanding the gene abnormalities that participate in the occurrence and development of breast cancer is the key to its prevention and treatment.
Nuclear factor-kappa B (NF-kB), the key transcription factor that mediates the inflammatory response, is involved in carcinogenesis-associated cellular processes, such as inflammation, proliferation, invasion, metastasis, angiogenesis, differentiation, and survival $[5,6]$. Studies have shown that NF-kB regulates the expression of several responsive genes that are associated closely with tumorigenesis, such as those encoding 
cytokines, transcription factors, growth factors, and apoptosis regulators [7]. Aberrant activation of NF- $\mathrm{NB}$ occurs in most cancers, including breast cancer [8-10]. Many negative regulators, including microRNAs, long non-coding RNAs, and regulatory proteins, function as tumor suppressors by inhibiting the uncontrolled activation of NF-kB [5, 6, 11].

CCCTC-binding factor (CTCF) is an evolutionarily conserved and ubiquitously expressed zinc finger protein. CTCF was originally discovered as a candidate tumor suppressor, given its ability to bind to the promoter of the oncogene c-myc to inhibit its expression [12]. As an epigenetic regulator, $\mathrm{CTCF}$ regulates the expression of several genes, including tumor suppressor genes p53 and p16 [13, 14] and pro-apoptotic gene bax [15]. Studies have identified approximately 20,000 CTCFbinding sites (CBS) in the human genome [16, 17]. $C T C F$ was considered as a possible target for deletions of chromosomal regions of 16q22.1 that occur commonly in breast and prostate cancers [18]. In recent years, CTCF has been found to be mutated sporadically in diverse cancer types, such as leukemia, breast, uterine, and prostate cancers [19-23] and is involved in inhibiting cancer cell growth and clonogenicity [24]. CTCF deletion has been reported in lobular carcinoma of the breast [25]. However, the exact role of CTCF in breast cancer is unclear.

In this study, we examined CTCF expression in breast cancer tissues and cell lines, and analyzed the correlation between CTCF expression and various clinicopathological parameters. Furthermore, the effects of CTCF on cell proliferation and migration were investigated through the overexpression or knockdown of CTCF in breast cancer cells. Transcriptome microarray analysis and validation experiments suggested that CTCF might inhibit the activation of the NF- $\mathrm{B}$ (p65) subunit and its target genes. Our experiments imply an important role for $\mathrm{CTCF}$ in inhibition of NF-kB over-activation in breast cancer occurrence and metastasis.

\section{RESULTS}

\section{CTCF is downregulated in breast cancer tissues and cell lines}

We first examined CTCF expression in human breast cancer cell lines MCF-7, SKBR3, and MDAMB-231 as well as normal breast cells MCF-10A. Western blotting analysis showed that CTCF was downregulated in the three breast cancer cell lines examined (Figure 1A). However, no significant change in the $C T C F$ mRNA level was observed in breast cancer cell lines as compared with that in MCF-10A (Supplementary Figure 1). The expression of CTCF was analyzed in only three breast cancer cell lines; therefore, further analysis was carried out to verify the difference in $C T C F$ expression using normal and tumor breast tissues. Quantitative real-time reverse transcription PCR (qRT-PCR) indicated that the $C T C F$ mRNA level was decreased significantly in human breast tumors $(n=20)$ compared with peritumoral tissues (Figure 1B). Moreover, immunohistochemical (IHC) analysis showed that the CTCF protein was downregulated significantly in breast cancer tissues $(n=66)$ compared with peritumoral tissues $(n=30)$ and fibroadenoma $(n=30)$ (Figure $1 \mathrm{C}, P<0.01)$. These results suggested that CTCF expression is downregulated in breast cancer tissues and cell lines

\section{Correlation between CTCF expression and clinicopathological parameters in breast cancer}

To investigate the clinical significance of CTCF downregulation in breast cancer, we analyzed the potential association between CTCF levels and clinical characteristics of paraffin-embedded breast cancer tissue specimens obtained from 66 patients $(17,24$, and 25 cases at stage I, II, and III/IV, respectively) (Table 1). No significant correlation was observed between CTCF levels and age, estrogen receptor, progesterone receptor, or human epidermal growth factor receptor-2 (HER-2) status, whereas a low CTCF level was associated significantly with pTNM stage $(P=0.043)$ and pathological differentiation $(P=0.029)$. Furthermore, the immunoreactive score of Remmele and Stegner (IRS) statistics for CTCF also indicated that the level of CTCF was downregulated significantly in stage III/IV tumors compared with that in stage I tumors (Figure 1D, $P=0.0098)$.

To determine the effect of CTCF on survival of breast cancer patients, we generated Kaplan-Meier survival curve of 3,951 patients with breast cancer with low or high CTCF expression using Kaplan-Meier Plotter (www.kmplot.com/analysis). The results showed that higher CTCF mRNA expression in patients with breast cancer correlated with an improvement in relapse-free survival (Supplementary Figure 2).

\section{CTCF suppresses breast cancer progression}

Our findings suggested an involvement of CTCF in breast cancer progression; therefore, we assessed the functional role of CTCF in the phenotype of breast cancer cells both in vitro and in vivo, via lentivirusmediated knockdown and overexpression of $C T C F$, using MCF-7 and MDA-MB-231 cells lines as a model system. Given the significant difference in $\mathrm{CTCF}$ protein levels between non-metastatic $\mathrm{MCF}-7$ and metastatic MDA-MB-231, we selected these two cell lines for subsequent functional studies. Knockdown of CTCF promoted $\mathrm{MCF}-7$ tumorigenicity and cell proliferation (Figure 2A, 2C and 2D). By contrast, ectopic overexpression of $C T C F$ attenuated MDA-MB-231 tumorigenicity and cell proliferation (Figure 2B, 2E and 2F). 
To determine if CTCF also inhibits metastasis and invasion in breast cancer, we performed wound healing and Transwell assays in vitro. As expected, $C T C F$ knockdown enhanced MCF-7 cell migration and invasion (Figure 3A and 3B), while CTCF overexpression inhibited MDA-MB-231 cell migration and invasion (Figure 3C and 3D).
To confirm the tumor suppressor role of CTCF in vivo, we established a xenograft model by inoculating nude mice with MDA-MB-231-CTCF or control cells. The in vivo assay indicated that enforced $C T C F$ expression suppressed tumor growth significantly in the xenograft nude mouse model (Figure 4A-4E). Taken together, these results suggested that CTCF functions as a tumor
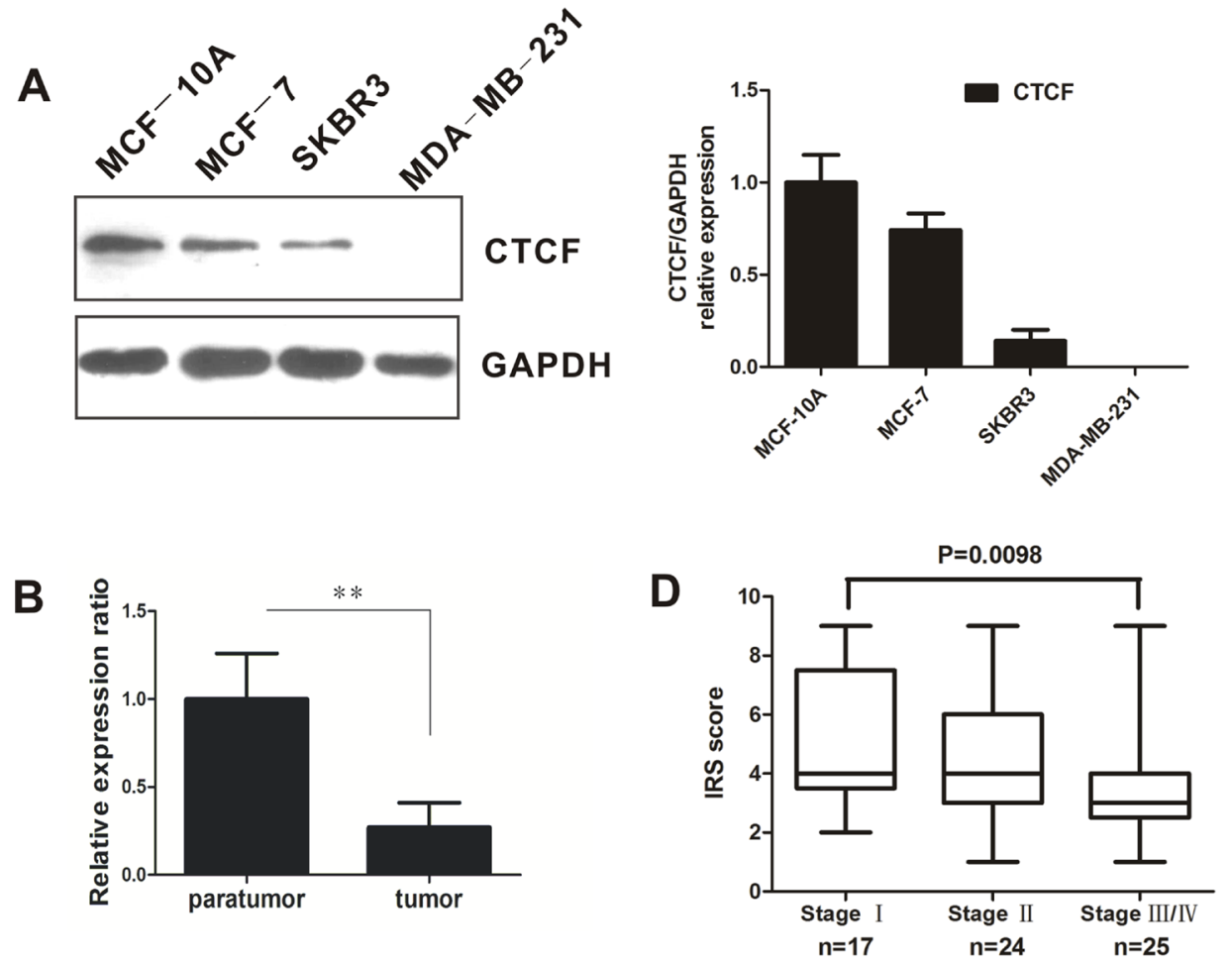

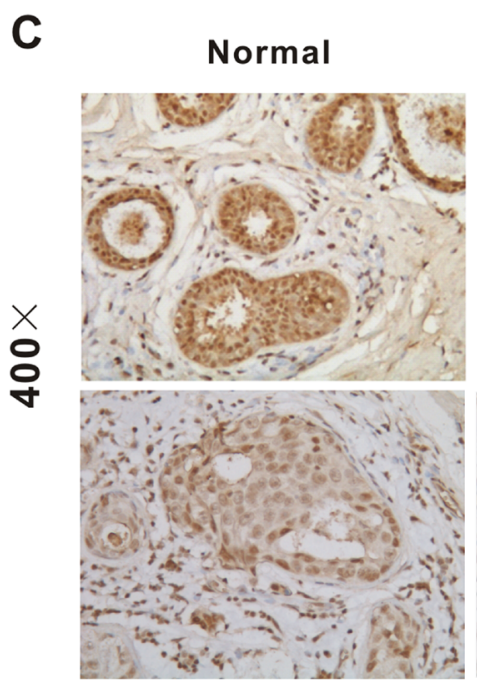

Stage I

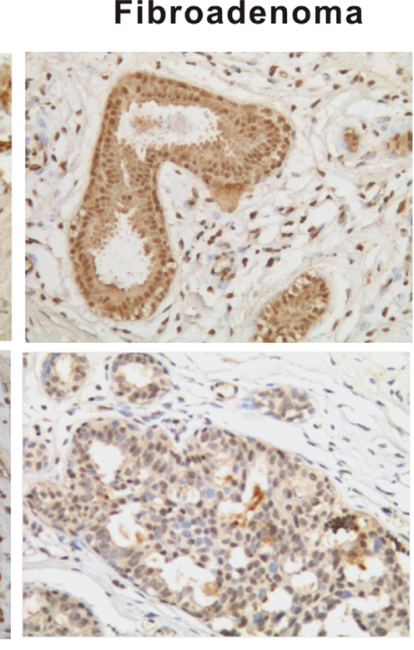

Stage II

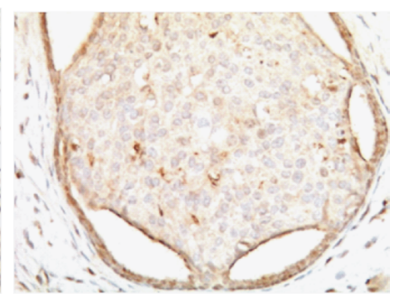

Stage III/IV

Figure 1: CTCF expression is downregulated in breast cancer tissues and cell lines. (A) CTCF expression in human mammary epithelial cell line MCF-10A and human breast cancer cell lines (non-metastatic MCF-7 and metastatic SKBR3 as well as MDAMB-231) was evaluated by western blotting analysis. GAPDH was used as an internal control. (B) Real-time quantitative PCR was used to detect the CTCF mRNA level in 20 fresh breast carcinoma tissues and corresponding peritumoral tissues. (C) Representative images of immunohistochemical staining for CTCF in normal breast tissues, fibroadenoma, and tumor tissues at the indicated clinical stages $(\times 400)$. (D) Immunoreactive score (IRS) of CTCF protein expression in patients at different clinical stages. ${ }^{* *}$ indicates $P<0.01$. 
Table 1: The association between CTCF expression and clinicopathological factors in patients with breast cancer

\begin{tabular}{|c|c|c|c|c|}
\hline \multirow[t]{2}{*}{ Characteristic } & \multirow[t]{2}{*}{$N$} & \multicolumn{2}{|c|}{ CTCF expression } & \multirow{2}{*}{$P$ value } \\
\hline & & High & Low & \\
\hline Age & & & & 0.661 \\
\hline$<50$ & 34 & 11 & 23 & \\
\hline$>50$ & 32 & 12 & 20 & \\
\hline pTNM stage & & & & 0.043 \\
\hline I & 17 & 8 & 9 & \\
\hline II & 24 & 11 & 13 & \\
\hline III/IV & 25 & 4 & 21 & \\
\hline Pathological differentiation & & & & 0.029 \\
\hline Well/moderate & 43 & 19 & 24 & \\
\hline Poor & 23 & 4 & 19 & \\
\hline ER status & & & & 0.147 \\
\hline Negative & 31 & 8 & 23 & \\
\hline Positive & 35 & 15 & 20 & \\
\hline PR status & & & & 0.450 \\
\hline Negative & 30 & 9 & 21 & \\
\hline Positive & 36 & 14 & 22 & \\
\hline HER-2 status & & & & 0.552 \\
\hline Negative & 34 & 13 & 21 & \\
\hline Positive & 32 & 10 & 22 & \\
\hline
\end{tabular}

ER: estrogen receptor; PR: progesterone receptor; HER-2: human epidermal growth factor receptor-2.

suppressor and plays a pivotal role in breast cancer progression.

\section{CTCF downregulates multiple target genes of NF-кB by inhibiting the activation of RELA (p65)}

We next investigated the underlying mechanism involved in CTCF-mediated inhibition of migration and invasion in breast cancer cells. Using total RNA isolated from $C T C F$-overexpressing and control MDA-MB-231 cells, we performed a cDNA microarray analysis to identify differentially expressed genes and pathways induced by CTCF. The global gene expression profiling identified 198 differentially expressed genes (fold change $>1.3$ and $P<0.05$ ). Among them, 65 genes were upregulated and 133 genes were downregulated (Figure 5A, Supplementary Table 1). Biological functional analysis of these differentially expressed genes using gene ontology (GO) and pathway enrichment analyses identified the top 10 most suppressed pathways, including colorectal cancer metastasis signaling (Supplementary Figure 3). Furthermore, disease and functional analysis showed that the significantly activated functions included organismal death $(\mathrm{Z}$-score $=3.409)$ and morbidity or mortality $(Z$-score $=3.383)$, while the significantly suppressed functions were migration of smooth muscle cells $(Z$-score $=-3.373)$ and survival of the organism (Z-score $=-3.332)$ (data not shown). Overall, these results suggested that CTCF might inhibit metastasis by regulating the expression of these genes.

We noted that more than $18 \%(36 / 198)$ of the differentially expressed genes corresponded to the target genes of NF- $\mathrm{kB}$ or RELA (p65) subunit, and most of these genes were downregulated upon $C T C F$ overexpression (Figure 5B). In addition, analysis of the microarray data for upstream regulation factors revealed inhibition of genes involved in the activation of NF- $\mathrm{KB}$ signaling pathway, including NF- $\mathrm{kB}$ complex and the RELA (p65) subunit (Supplementary Figure 4). In the subsequent qRT-PCR validation, we selected $30 \mathrm{NF}-\kappa \mathrm{B}$ target genes associated with proliferation and metastasis (Table 2). The qRT-PCR analysis showed that $C T C F$ overexpression in MDAMB-231 cells resulted in a significant downregulation of most of the NF- $\mathrm{KB}$ target genes (Figure 6A). Among the 30 target genes, the qRT-PCR results for 22 of them were consistent with the GeneChip results. We also detected the encoded protein levels of several selected genes, including early growth response protein 1 (EGR1), tumor necrosis factor alpha-induced protein 3 (TNFAIP3), and growth 
arrest and DNA-damage-inducible alpha (GADD45A), which are important $\mathrm{NF}-\kappa \mathrm{B}$ target genes and showed maximum changes in their expression (Table 2). Western blotting analysis showed that the protein levels of EGR1, TNFAIP3, and GADD45A were also downregulated in $C T C F$-overexpressing MDA-MB-231 cells (Figure 6B).

As NF- $\kappa B$ p65 subunit phosphorylation is the main marker of $\mathrm{NF}-\kappa \mathrm{B}$ activation, we examined the effect of CTCF on p65 phosphorylation in MCF-7 and MDA-MB-231 cells. Western blotting analysis showed that the ectopic overexpression of $C T C F$ attenuated p65 phosphorylation, whereas knockdown of CTCF promoted p65 phosphorylation (Figure 7A). Moreover, the luciferase assay using a luciferase reporter construct bearing six canonical NF- $\mathrm{B}$ p 65 binding sites indicated that the downregulation of phospho-p65 (Ser536) induced by
A

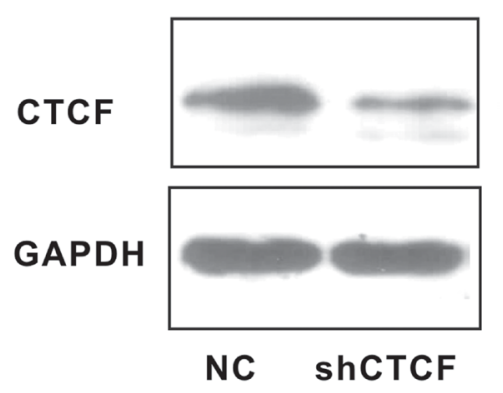

C

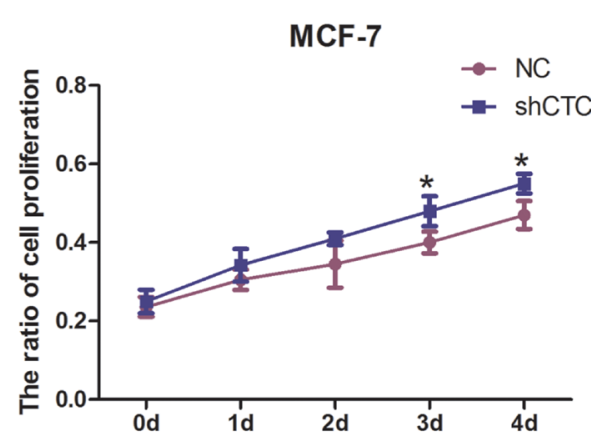

D
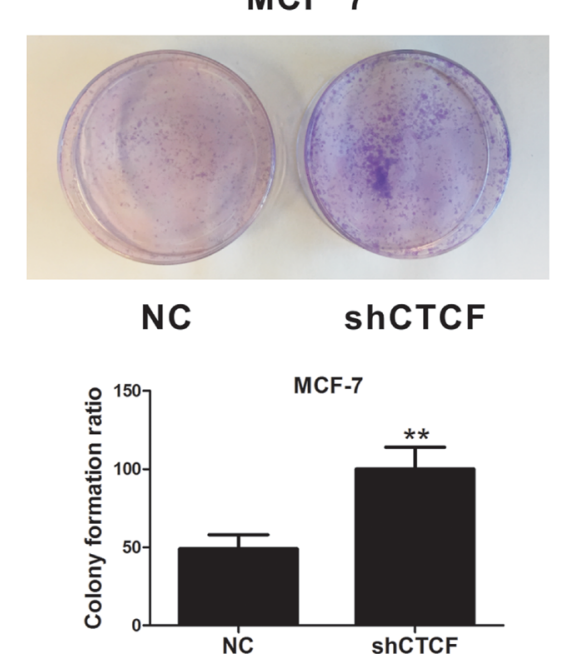

B

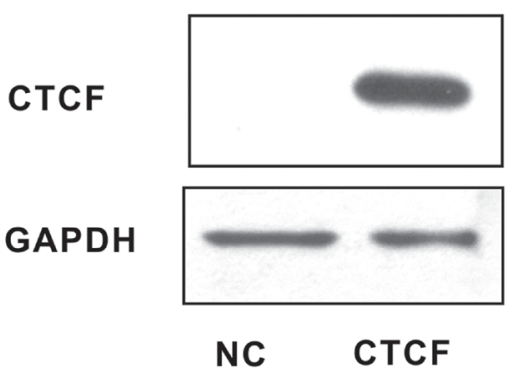

E

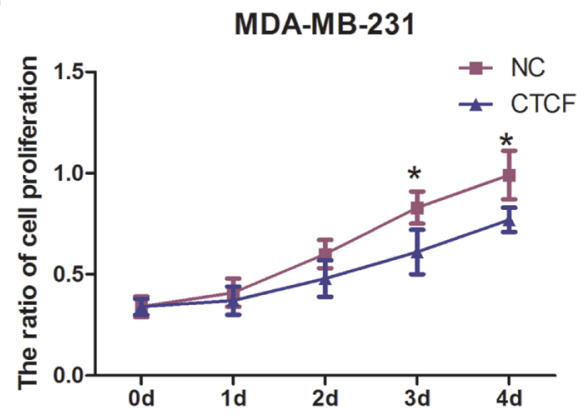

F

MDA-MB-231

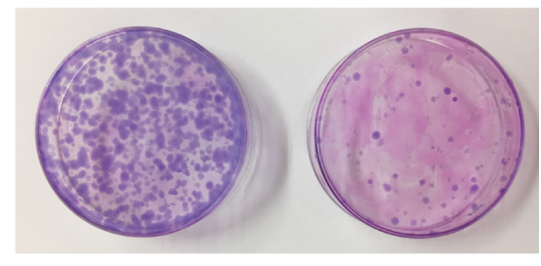

NC

CTCF

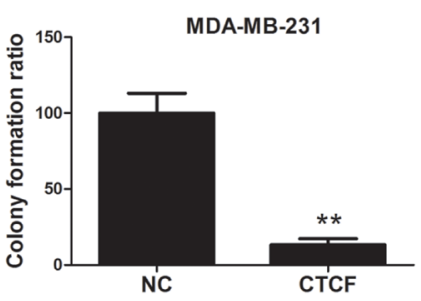

Figure 2: CTCF suppresses breast cancer cell proliferation and tumorigenicity. Western blotting analysis confirmed $C T C F$ knockdown in MCF-7 cells stably infected with lentiviral particles carrying the shCTCF vector (A) and overexpression in MDA-MB-231 cells stably infected with lentiviral particles carrying the $C T C F$ vector (B). The effect of CTCF knockdown (C) and overexpression (D) on breast cancer cell proliferation was determined by the MTT assay. The effect of CTCF knockdown (E) and overexpression (F) on tumorigenicity of breast cancer cells was detected using a colony formation assay. ${ }^{*} P$ indicates $<0.05,{ }^{* *}$ indicates $P<0.01$. 
Table 2: Selected NF-KB target genes related to cell proliferation and metastasis influenced by CTCF overexpression in MDA-MB-231 cells

\begin{tabular}{|c|c|c|c|}
\hline Gene symbol & Entrez gene ID & Fold change & $P$ value \\
\hline$E G R 1$ & NM_001964 & -5.8429036 & 0.00072380295 \\
\hline$L T B$ & NM_002341 & -2.0426607 & 0.00080019515 \\
\hline TNFAIP3 & NM_006290 & -2.0378265 & 0.0002301113 \\
\hline CXCL2 & NM_002089 & -1.947091 & 0.00072380295 \\
\hline GADD45A & NM_001924 & -1.9072746 & 0.00035669992 \\
\hline ILIA & NM_000575 & -1.8493568 & 0.0006018482 \\
\hline GDF15 & NM_004864 & -1.8099316 & 0.0014306399 \\
\hline CCL5 & NM_002985 & -1.7817189 & 0.0014670709 \\
\hline KLF10 & NM_005655 & -1.7360209 & 0.0007831317 \\
\hline$A T F 3$ & NM_001030287 & -1.7178577 & 0.0016058085 \\
\hline TRIB3 & NM_021158 & -1.7063142 & 0.0012432608 \\
\hline IL24 & NM_001185156 & -1.6383375 & 0.00093471195 \\
\hline CXCL3 & NM_002090 & -1.6109521 & 0.0018206392 \\
\hline$I L 7 R$ & NM_002185 & -1.5548722 & 0.00026126512 \\
\hline IL6 & NM_000600 & -1.4467697 & 0.0006270534 \\
\hline IFIH1 & NM_022168 & -1.4459864 & 0.000837096 \\
\hline$E D N R B$ & NM_001201397 & 1.4439552 & 0.001778671 \\
\hline TRAF1 & NM_005658 & -1.3759115 & 0.0021421628 \\
\hline$L M N B 1$ & NM_005573 & -1.357773 & 0.0010687009 \\
\hline$A P P$ & NM_201414 & -1.3555276 & 0.005037326 \\
\hline$I N H B A$ & NM_002192 & -1.3478045 & 0.005553174 \\
\hline$J U N B$ & NM_002229 & -1.3321716 & 0.013992447 \\
\hline SDC4 & NM_002999 & -1.332132 & 0.00073019817 \\
\hline$P T G S 2$ & NM_000963 & -1.332128 & 0.0211235 \\
\hline ENPP1 & NM_006208 & 1.3278843 & 0.016963318 \\
\hline$C E B P B$ & NM_001285879 & -1.3265668 & 0.009680476 \\
\hline DUSP1 & NM_004417 & -1.319924 & 0.0027198044 \\
\hline$C F B$ & NM_001710 & -1.3132958 & 0.00087543245 \\
\hline$E G F R$ & NM_005228 & -1.3061141 & 0.0036412638 \\
\hline CASP 8 & NM_001080125 & 1.3000749 & 0.0020934197 \\
\hline
\end{tabular}

$C T C F$ overexpression resulted in a significant reduction in luciferase activity (Figure 7B). To further establish the physical and functional interaction between p65 Ser536 and the differentially expressed NF- $\mathrm{kB}$ target genes, we performed a chromatin immunoprecipitation (ChIP) assay using the TNFAIP3 gene as an example. Real-time ChIPPCR showed that the occupancy of the TNFAIP 3 promoter by 065 was decreased in MDA-MB-231 cells in response to $C T C F$ overexpression (Figure 7C).

\section{DISCUSSION}

Several studies have identified that CTCF deletions or mutations are associated with human breast 
carcinogenesis [23, 25]. However, the precise role of CTCF in breast cancer and the underlying molecular mechanism remain largely unknown. In this study, we showed that CTCF protein levels, but not mRNA expression, were downregulated in breast cancer cells, indicating that post-transcriptional CTCF regulation plays an important role in breast cancer cells. In addition, CTCF levels in breast cancer lesions were significantly lower than those in peritumoral tissues. IHC analysis showed that the decrease in CTCF level was associated significantly with pTNM stage and pathological differentiation. Analysis of the publicly available datasets (Kaplan-Meier Plotter) revealed a correlation between a decreased CTCF mRNA level and poor prognosis in breast cancer patients. However, we found no significant difference in CTCF mRNA levels in three breast cancer cell lines examined. The differences between cell lines and tissues may be explained by the differences in cellular environment, cell type and genetic background. Taken together, these findings provided strong evidence that the downregulation of CTCF enhances breast cancer progression.

In agreement with previous studies in other human cancers $[24,26]$, we found that CTCF might inhibit cell proliferation in breast cancer cells. We reported, for the first time, that $C T C F$ knockdown increased cell migration and invasion in breast cancer cells. By contrast, CTCF overexpression markedly reduced the migration and invasion of cancer cells in vitro and tumorigenicity in vivo. Thus, our in vivo results were consistent with those observed in vitro, further confirming that CTCF suppresses the tumorigenicity of breast cancer cells. Our findings indicated a tumor suppressor role of CTCF in the development and progression of breast cancer. A recent study reported that $\mathrm{CTCF}$ exhibits oncogenic activity that enhances the aggressiveness and progression of neuroblastoma by promoting growth, invasion, and metastasis in neuroblastoma cells [27]. Thus, CTCF may play different roles in different cancers.

Aberrant or constitutive activation of NF-kB in breast cancer cells is associated with high malignancy and the promotion of osteolytic bone metastasis $[28,29]$. RELA (p65), the major transactivating subunit of $\mathrm{NF}-\kappa \mathrm{B}$, is responsible for the activation of downstream genes that participate in multiple cellular processes related to carcinogenesis [30]. Transcriptional profile analysis and real-time PCR verification revealed the downregulation of several NF- $\mathrm{kB}$ target genes in $C T C F$-overexpressing MDA-MB-231 cells. Microarray data analysis of upstream regulation factors indicated the CTCF-mediated inhibition of the NF- $\kappa$ B complex and RELA (p65) activation, which was validated by the luciferase reporter assay. CTCF is thought to decrease p65 phosphorylation and attenuate its DNA-binding ability. The mechanisms underlying CTCF's inhibition of NF- $\mathrm{kB}$ activity will be explored in future studies, including the possibility of physical interaction. Does CTCF bind to NF-kB promoter/enhancer region? Does it need co-activators/co-repressors? These questions are all the directions of our future studies. The results of the present study suggested that the CTCF/NF-kB pathway might be involved in the development of breast cancer. Interestingly, $C T C F$ has been reported as a downstream target gene of the

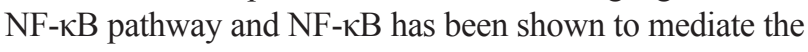
upregulation of $C T C F$ expression directly [31,32]. Thus, our results suggest that it would be reasonable to investigate whether CTCF and NF- $\mathrm{kB}$ exist in a feedback regulatory loop and to analyze their regulatory effect on each other.

In this study, CTCF induced the inhibition of several NF- $\mathrm{kB}$ target genes, which further confirmed
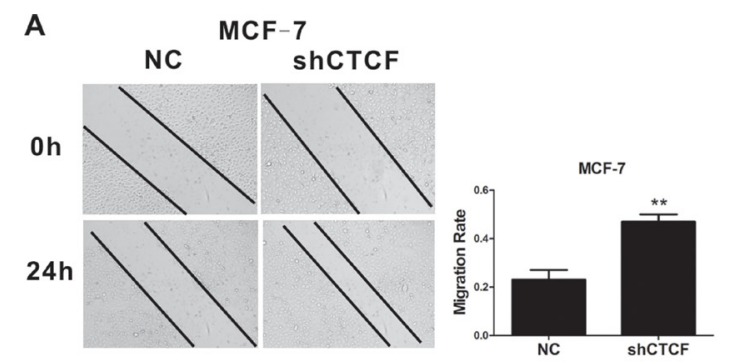

C

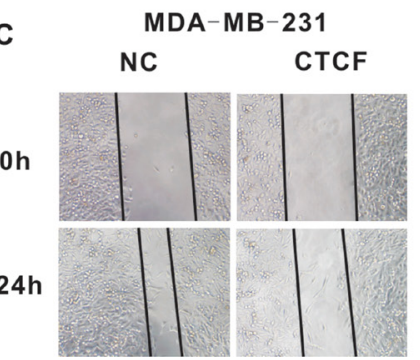

MDA-MB-231

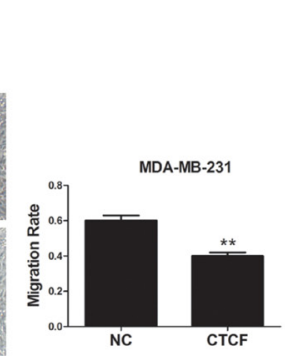

B

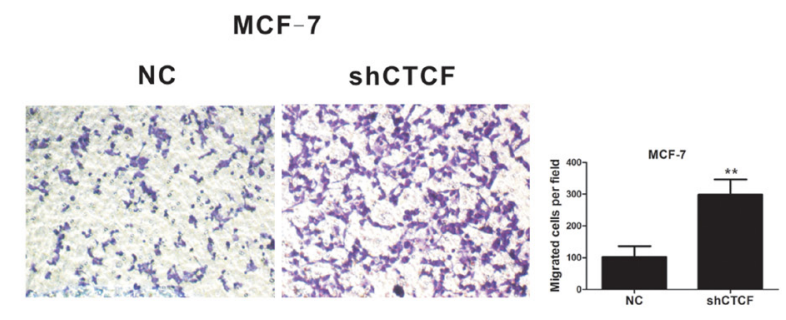

D

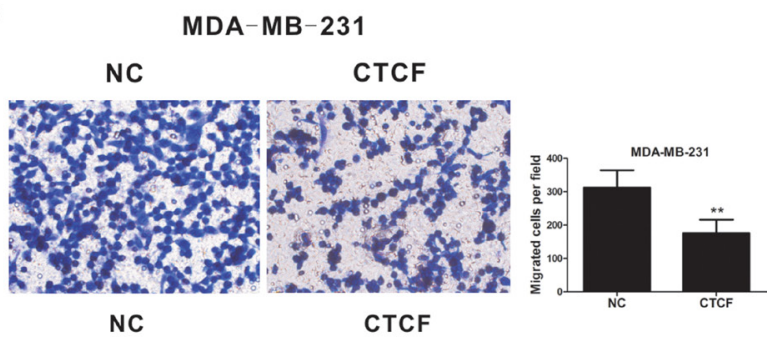

Figure 3: CTCF inhibits breast cancer cell migration and invasion. Wound healing (A and C) and Transwell (B and D) assays were performed to detect the effect of $C T C F$ knockdown (A and $\mathbf{B})$ and overexpression $(\mathbf{C}$ and $\mathbf{D})$ on migration and invasion in breast cancer cells. The left panel is a representative image and the right panel shows the average number per field. ${ }^{* *}$ indicates $P<0.01$. 
the CTCF-mediated inhibition of NF- $\kappa \mathrm{B}$ activity. The majority of the altered target genes are associated with proliferation and metastasis. The most affected genes included TNFAIP3, EGR1, and GADD45a. TNFAIP3, also known as A20, encodes an ubiquitin-editing enzyme and its overexpression is associated with breast cancer aggressiveness [33]. EGR1 is a mammalian nuclear transcription factor with an indispensable role in breast cancer proliferation, migration, chemoinvasion, and angiogenesis [34-36]. GADD45a is reported to promote Myc-driven breast cancer, resulting in increased tumor vascularization and growth [37]. Taken together, CTCF acts as a tumor suppressor in breast cancer by inhibiting the activation of NF- $\kappa \mathrm{B}$ (p65) and its target genes. Thus, CTCF might be an effective therapeutic target for the treatment of breast cancer.

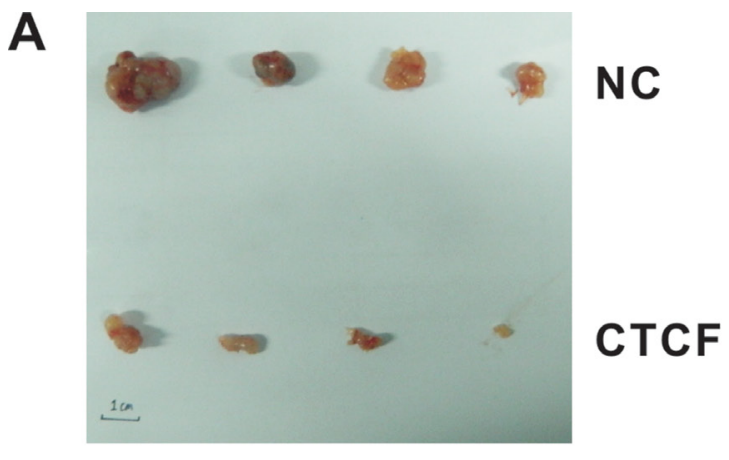

B
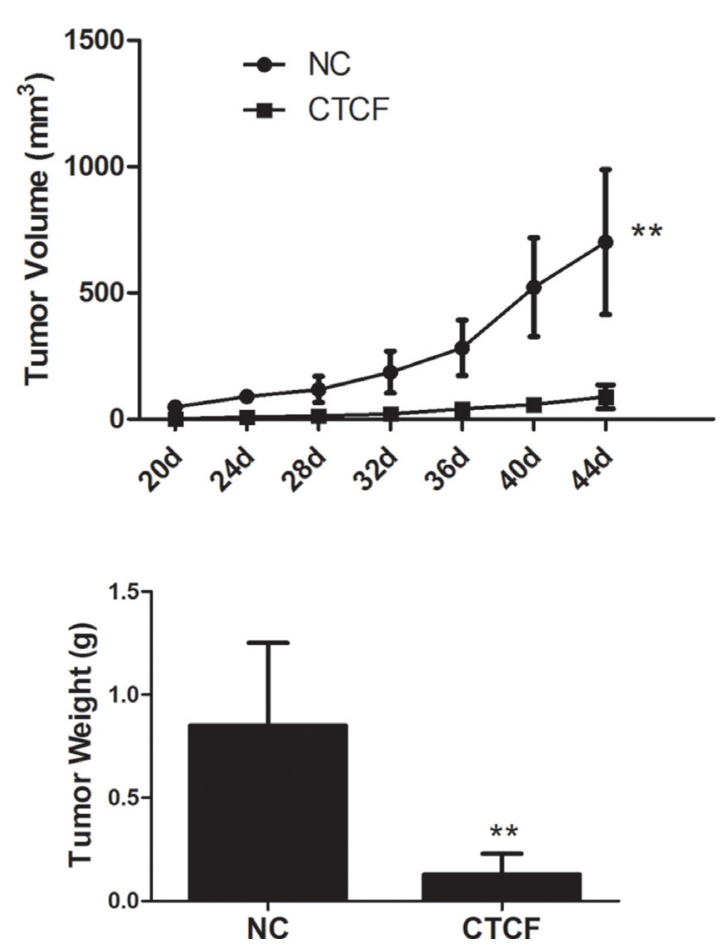

\section{MATERIALS AND METHODS}

\section{Cell culture and plasmid constructs}

MCF-7, MDA-MB-231, and 293T cells were maintained in Dulbecco's Modified Eagle's Medium (DMEM, GIBCO). SKBR3 cells were cultured in Roswell Park Memorial Institute (RPMI)-1640 medium (GIBCO). All media were supplemented with $10 \%$ fetal bovine serum (FBS, HyClone). The human epithelial breast cell line, MCF-10A, was maintained in DMEM containing $0.5 \mu \mathrm{g} / \mathrm{mL}$ hydrocortisone, $10 \mu \mathrm{g} / \mathrm{mL}$ insulin, $20 \mathrm{ng} / \mathrm{mL}$ human epidermal growth factor (EGF), and 5\% heatinactivated horse serum. All cell lines were obtained from the Cell Resource Center, Peking Union Medical College. Cell lines were free of mycoplasma contamination,

D

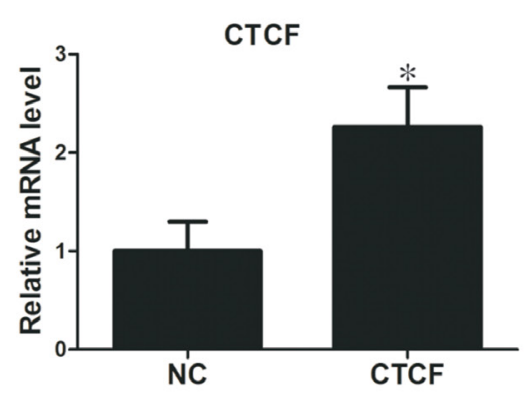

E

\section{NC CTCF}

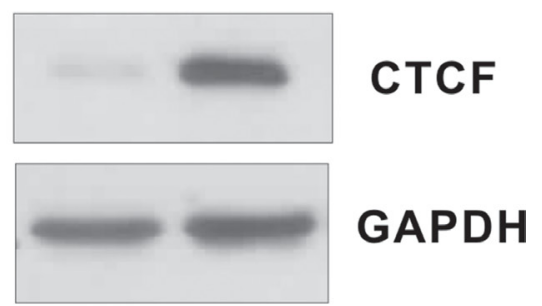

Figure 4: CTCF inhibits tumorigenicity of breast cancer cells in vivo. (A) A xenograft nude mouse model was inoculated with either $C T C F$-overexpressing MDA-MB-231 cells or control cells ( $n=5 /$ group) and the tumor was isolated on day 44. (B) Xenograft tumor growth curves. (C) Mean weights of xenografts tumors. (D and E) CTCF mRNA and protein levels in xenograft tumors were measured using qRT-PCR and western blotting analysis. ${ }^{*}$ indicates $P<0.05,{ }^{* *}$ indicates $P<0.01$. 
according to PCR analysis. The species of origin was confirmed using PCR, and the identity of the cell lines was authenticated using short tandem repeat (STR) profiling (FBI, CODIS). The full-length CTCF coding sequence was synthesized chemically and subcloned into lentivirus vector GV358 (GeneChem, Shanghai, China). MDAMB-231 cells stably expressing CTCF and control cells were established by lentivirus-mediated gene transfer.

\section{Tissue samples}

We analyzed retrospectively the clinicopathological data of 66 patients diagnosed with breast cancer who underwent surgical resection at the Department of Breast surgery, Peking Union Medical College Hospital from January to October 2014. All specimens were determined as invasion ductal carcinoma by pathological

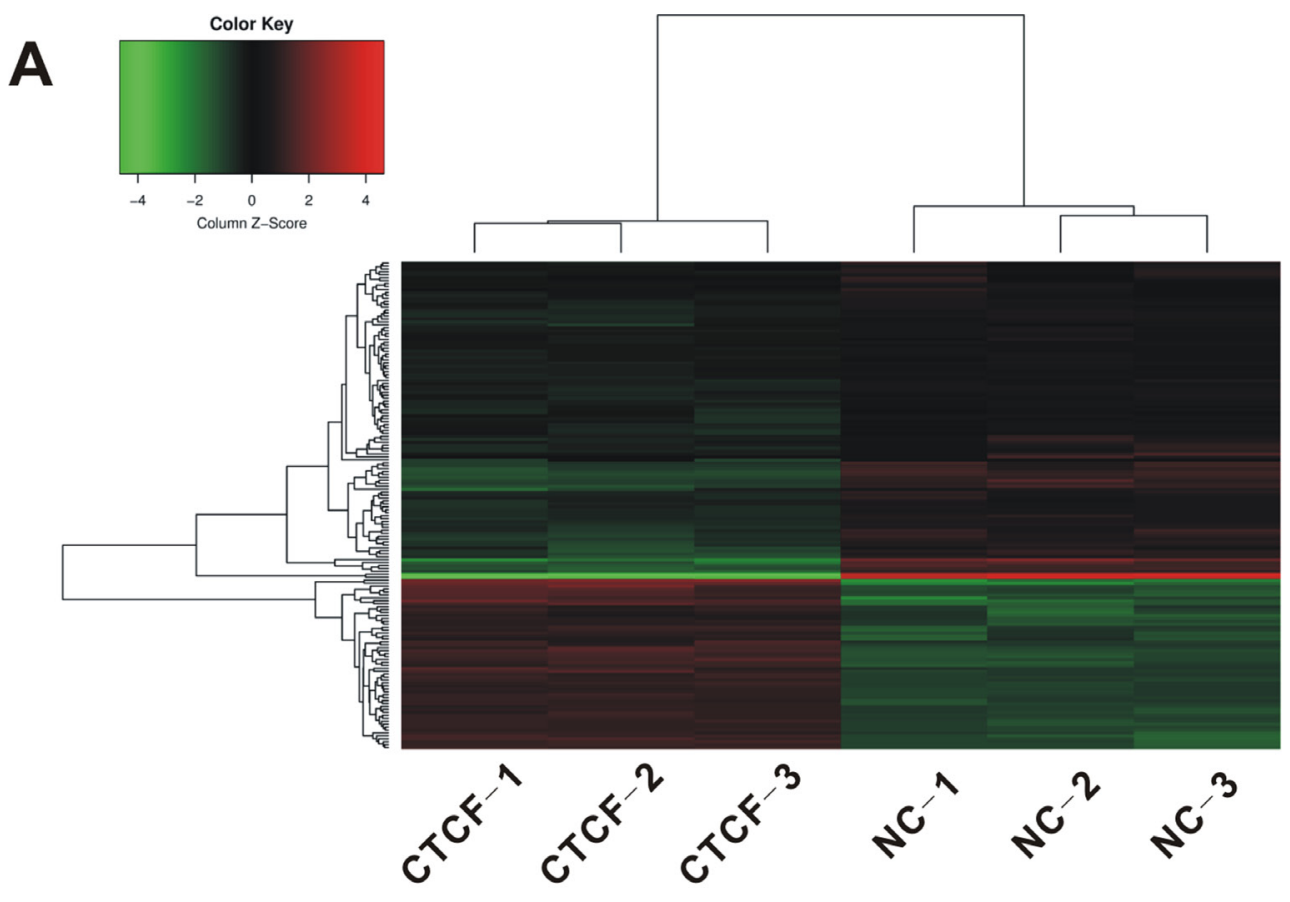

B
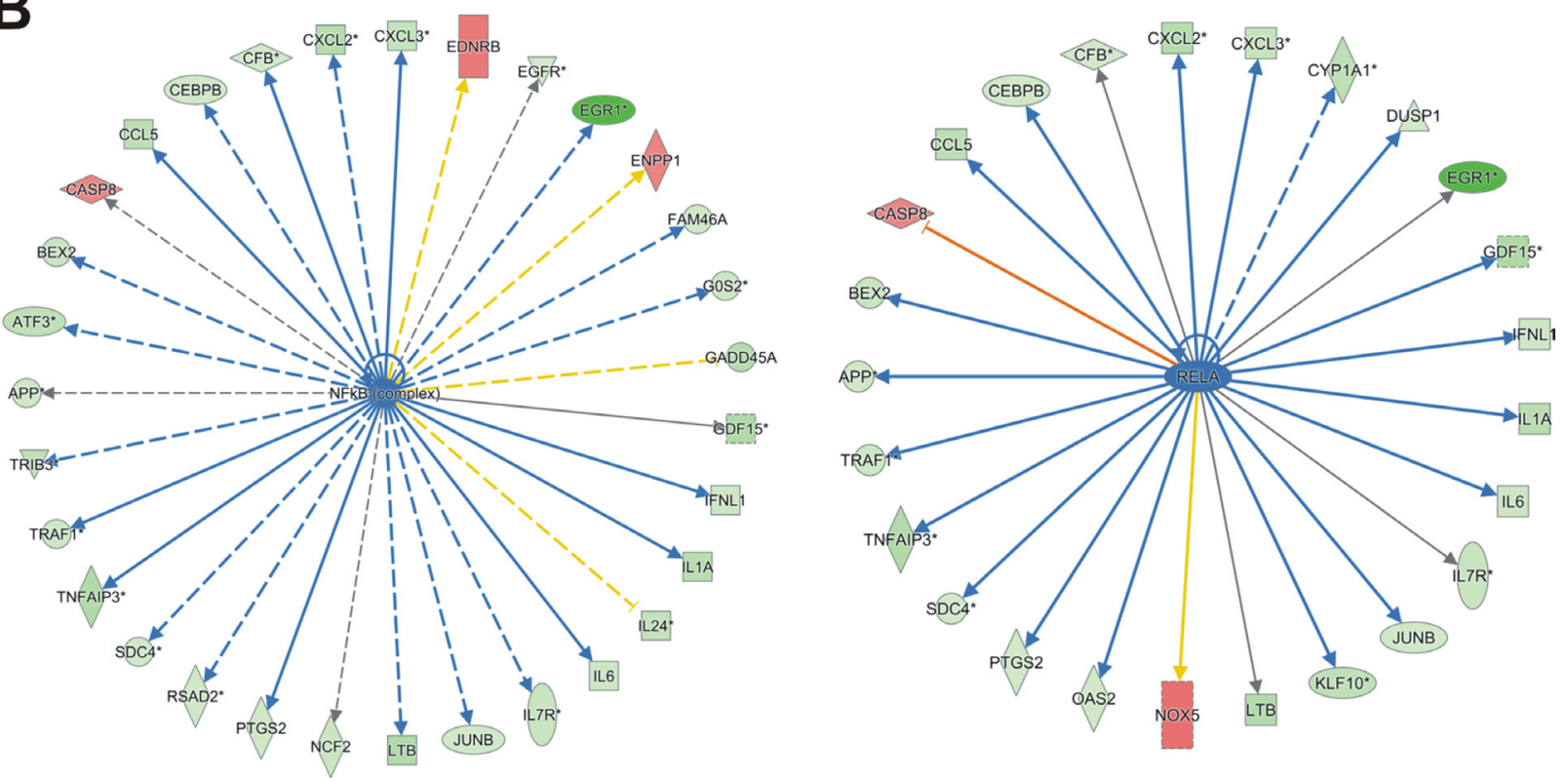

Figure 5: Identification of differentially expressed genes in MDA-MB-231 cells overexpressing CTCF. Total RNA was extracted from the $C T C F$-overexpressing MDA-MB-231 cells and control cells, and gene expression microarray was performed as described in "Materials and Methods". (A) Changes in gene expression $>1.3$ fold and $P<0.05$ are illustrated by a heat map. Green indicates relatively low expression and red indicates relatively high expression. (B) Of 198 differentially expressed genes, 36 are target genes of the NF- $\kappa$ B complex or RELA (p65). Green indicates downregulated genes and red indicates upregulated genes. 
examinations. Informed consent was obtained from each patient included in this study, and the study, along with the procedures used, was approved by the Institutional Research Ethics Committee of PUMCH. Tumors were classified histologically according to the TNM staging criteria from the American Joint Committee on Cancer (AJCC). Tumor grade was evaluated as per the World Health Organization (WHO) criteria.

\section{Immunohistochemistry (IHC) assay}

Immunohistochemistry was performed according to the standard protocol. Briefly, sections of paraffinembedded tissue (4- $\mu \mathrm{m}$ thick) were deparaffinized with xylene and hydrated in gradient diluted alcohol solutions. Endogenous peroxidase was blocked by incubation in 3\% hydrogen peroxide. High-pressure cooking was applied to retrieve the antigen and 5\% normal goat serum was used to block non-specific protein binding. Slides were incubated with the primary anti-CTCF antibodies (1:100, Millipore) overnight at $4{ }^{\circ} \mathrm{C}$, followed by probing with anti-rabbit secondary antibodies for $1 \mathrm{~h}$. Finally, all slides were stained with diaminobenzidine and counterstained with hematoxylin. Slides incubated with phosphatebuffered saline (PBS) instead of primary antibody were used as the negative control. The intensity of staining was graded according to the following criteria: 0 (no staining), 1 (weak staining = light yellow), 2 (moderate staining = yellow brown), and 3 (strong staining = brown). The proportion of positive-staining tumor cells was scored as follows: 0 (no positive cells), 1 ( $<10 \%$ positive cells), 2 (10-50\% positive cells), and 3 ( $>50 \%$ positive cells). The IRS was calculated by multiplying the staining intensity and staining-positive proportion scores, with an IRS $\leq 4$ considered as low expression and $>4$ as high expression.

\section{RNA isolation and quantitative reverse transcription polymerase chain reaction (qRT-PCR)}

Total RNA was extracted using the Trizol reagent (Life Technologies, Carlsbad, CA, USA) and first strand complementary DNA (cDNA) generated by the Reverse Transcription System (Takara) in a $20-\mu \mathrm{L}$ reaction containing $2 \mu \mathrm{g}$ total RNA, according to the manufacturer's protocol. Real-time PCR was performed
A
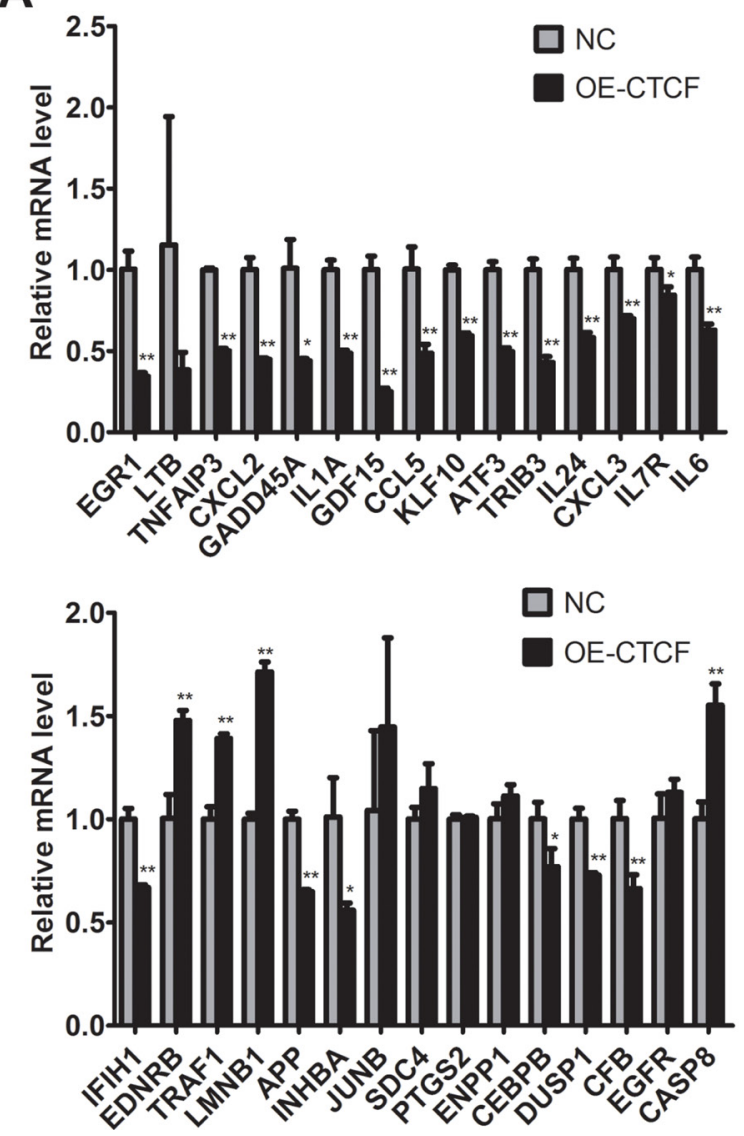

B

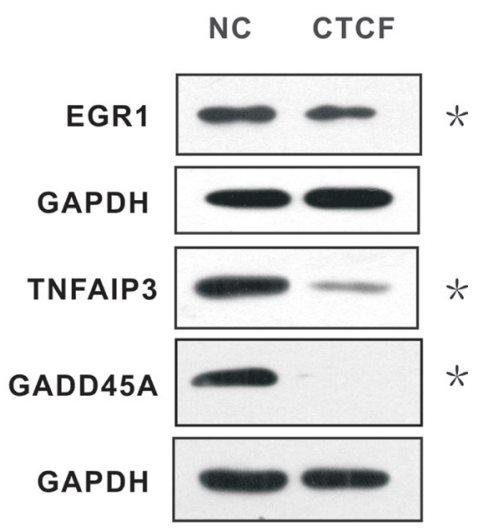

Figure 6: CTCF overexpression downregulates multiple NF-кB target genes in MDA-MB-231 cells. (A) Real-time RT-PCR analysis of the expression of NF- $\mathrm{KB}$ target genes identified by the cDNA microarray in the $C T C F$-overexpressing and control MDA-MB-231 cells. (B) Western blotting analysis of the expression of three NF- $\mathrm{BB}$ target genes in the $C T C F$-overexpressing and control MDA-MB-231 cells. *indicates $P<0.05,{ }^{* *}$ indicates $P<0.01$. 
on a Roche LightCycler 480 using a SYBR Green reaction mix (Takara). Values are shown means and standard deviations (SD) of the results from at least three independent experiments. All primer sets are available upon request.

\section{RNA interference and lentivirus package}

Cell lines stably expressing CTCF and negative control (NC) small hairpin RNA (shRNA) were established using a lentivector-based shRNA expression system. CTCF- or NC-shRNA were inserted into the lentivirus expression plasmid GV248 (GeneChem, Shanghai, China) with the following sequences: shCTCF, 5'-GGTGTAAAGAAGACATTCC-3' and non-silencing shRNA, 5'-TTCTCCGAACGTGTCACGT-3'. Plasmids were transfected into $293 \mathrm{~T}$ cells along with packaging plasmids pHelper 1.0 and pHelper 2.0 (pVSVG-I and pCMV $\triangle \mathrm{R} 8.92$ plasmids, respectively). Viral supernatants were collected after $48 \mathrm{~h}$ of transfection to infect breast cancer cells MCF-7, as described in the supplier's protocol. CTCF knockdown efficiency was determined by qRT-PCR and western blotting.

\section{Western blotting analysis}

Whole cell lysates were used for western blotting analysis as previously described [38, 39], with glyceraldehyde 3-phosphate dehydrogenase (GAPDH) used as a loading control. The anti-CTCF antibody (07-729) was obtained from Millipore, while antibodies against EGR1 (ab54966), TNFAIP3 (ab74037), GADD45A (ab180768), and p65 (ab16502) were obtained from Abcam; a GAPDH monoclonal antibody (SC-32233) and rabbit or mouse secondary antibodies were purchased from Santa Cruz Biotechnology. The anti-phospho-NF$\kappa \mathrm{B}$ p65 (Ser536) (93H1) antibody was obtained from Cell Signaling.

\section{3-(4,5-dimethylthiazol-2-yl)-2,5- diphenyltetrazolium bromide (MTT) assay}

MCF-7 or MDA-MB-231 cells were seeded at 5,000 cells/well into 96-well plates in $200 \mu \mathrm{L}$ fresh medium. After incubation for an appropriate interval, a $20-\mu \mathrm{L}$ stock MTT solution ( $5 \mathrm{mg} / \mathrm{mL}$ ) was added to each well. Following incubation for $4 \mathrm{~h}$, the medium was aspirated
A

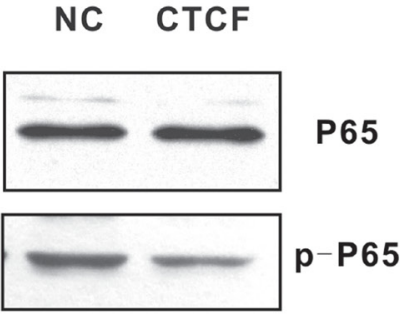

MDA-MB-231

B

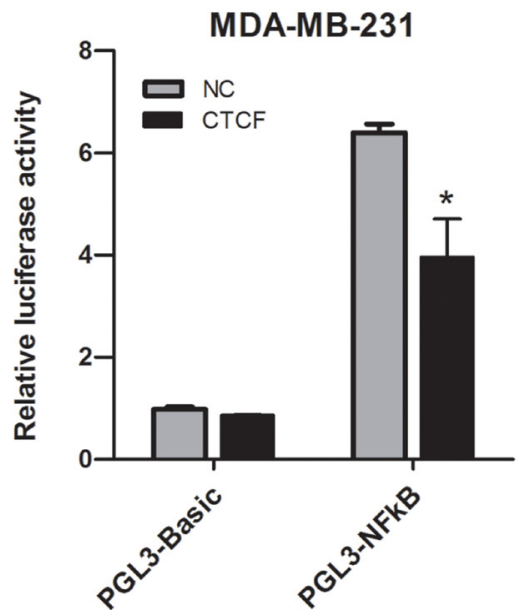

NC shCTCF

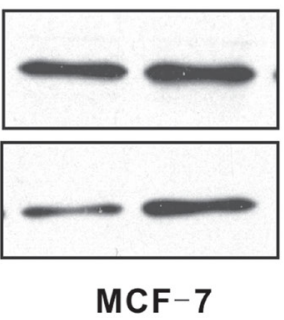

C

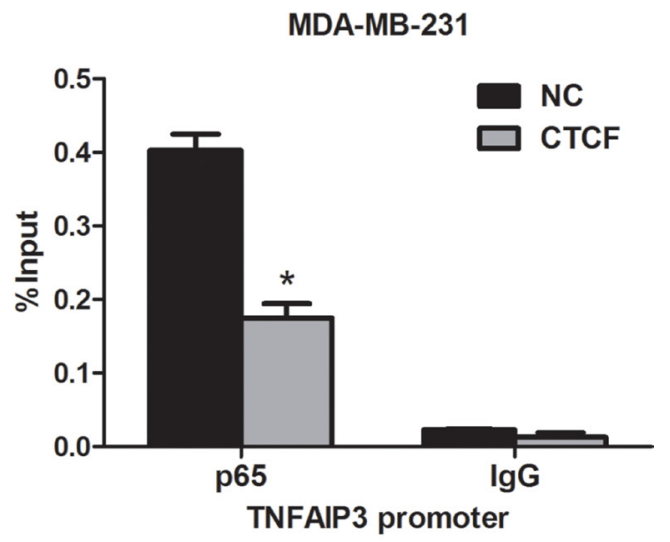

Figure 7: CTCF inhibits NF-кB (p65) activation. (A) The levels of p65 and p-p65 in the CTCF-overexpressing MDA-MB-231 cells and $C T C F$-knockdown MCF-7 cells were detected using western blotting analysis. (B) CTCF-overexpressing and control MDAMB-231 cells were transiently transfected with either empty vector pGL3-Basic or luciferase reporter pGL3-NFkB bearing six canonical NF-kB binding sites. Forty-eight hours after transfection, the luciferase activity was measured. (C) ChIP analysis was performed to detect p65 occupancy at the TNFAIP3 promoter in the $C T C F$-overexpressing and control MDA-MB-231 cells. Data represent three independent experiments. Error bars represent the standard error of the mean. *indicates $P<0.05$. 
and cells were treated with $150 \mu \mathrm{L}$ dimethyl sulfoxide for $10 \mathrm{~min}$. The absorbance of each well was measured at a wavelength of $490 \mathrm{~nm}$. All experiments were conducted in triplicate and repeated three times.

\section{Colony formation assays}

MCF-7 or MDA-MB-231 cells were plated at 500 or 100 cells into 60 -mm dishes and cultured for 7 or 14 days, respectively. Colonies were fixed with methyl alcohol for $30 \mathrm{~min}$, stained with Giemsa for $30 \mathrm{~min}$, and counted. Colonies containing at least 50 cells were scored. Each assay was performed in triplicate.

\section{Transwell assay}

Cell invasion was assessed using the Transwell assay. MCF-7 or MDA-MB-231 cells were harvested after trypsinization and washed with a serum-free medium containing $0.1 \%$ bovine serum albumin. Cells were diluted to $5 \times 10^{5}$ cells $/ \mathrm{mL}$ and $100 \mu \mathrm{L}$ of the cell suspension was seeded on the top of Matrigel invasion chambers $(8 \mu \mathrm{m}$ pore size, Corning, Cat No. 354480). The lower chamber was filled with $600 \mu \mathrm{L}$ medium containing 10\% FBS. After incubation for $24 \mathrm{~h}$ at $37^{\circ} \mathrm{C}$, cells from the upper chamber were gently removed with a cotton swab. The filter was fixed with $4 \%$ paraformaldehyde for $15 \mathrm{~min}$, stained with $500 \mu \mathrm{L} 0.1 \%$ crystal violet for $15 \mathrm{~min}$, washed with PBS, and counted under a light microscope to determine cell invasion. All experiments were conducted in triplicate and repeated three times.

\section{Wound healing assay}

MCF-7 or MDA-MB-231 cells were seeded into a 6-well plate and grown to $90 \%$ confluence in a complete medium. Cells were wounded using a plastic tip, washed with PBS to remove cell debris, and incubated in low serum medium $(0.5 \% \mathrm{FBS})$ for up to $24 \mathrm{~h}$. Cells were photographed under a microscope equipped with a camera at different time points.

\section{Xenograft tumor model}

Female BALB/c-nude mice (4-5 weeks old, 14-16 g) were purchased from the Charles River Laboratories of Beijing and housed in barrier facilities with a $12 \mathrm{~h} / 12 \mathrm{~h}$ light/dark cycle. All mouse experiments were performed according to the institutional guidelines and approved by the Institutional Animal Care and Use Committee (IACUC). Mice were divided randomly into two groups ( $n=5 /$ group). For tumor cell implantation, $5 \times 10^{6}$ MDA-MB-231 cells $(100 \mu \mathrm{L}$ volume $)$ transfected with CTCF or NC lentivirus were injected subcutaneously into the mice. Tumors were detected on day 20 after injection and then examined once every 4 days. Tumor length, width, and thickness were measured using a caliper and tumor volume was calculated by the ellipsoid volume calculation formula: $0.5 \times\left(\right.$ length $\times$ width $\left.^{2}\right)$. At day 44 after injection, animals were euthanized and the tumors excised and weighed.

\section{GeneChip microarray analysis and data normalization}

Total RNA from MDA-MB-231 cells transfected with NC- or CTCF-OE-lentivirus $(n=3)$ was extracted using the Trizol reagent. A NanoDrop 2000 and Agilent Bioanalyzer 2100 were used for quantitative and qualitative RNA detection, respectively. The GeneChip PrimeView Human Gene Expression Array (Affymetrix) was used for microarray processing to determine the gene expression profile, according to the manufacturer's instruction. Significant differences in gene expression between MDA-MB-231 cell treated with NC- and CTCFOE-lentivirus were identified as follows: $P<0.05$ and the absolute fold change $>1.3$. The GeneChip data has been submitted to the NCBI Gene Expression Omnibus and is accessible through GEO series accession number GSE98337.

\section{Luciferase reporter assays}

Analysis of NF-kB activity was performed by cloning six canonical NF-kB RELA (p65) binding sites upstream of the luciferase gene in the pGL3-basic reporter vector. MDA-MB-231 cells overexpressing CTCF were transfected with the luciferase reporter and pRL-TK plasmid. After $48 \mathrm{~h}$, cells were lysed with passive lysis buffer and the lysates were analyzed for both firefly and Renilla luciferase activity using a dual-luciferase reporter assay kit (Promega). Luciferase activity was normalized for transfection efficiency using the pRL-TK reporter (Promega) as an internal control. A Centro XS ${ }^{3}$ LB 960 Microplate Luminometer (Berthold) was used according to the manufacturer's instructions. The results are expressed as the percentages of relative luciferase activities of the control, which was set as $100 \%$.

\section{Chromatin immunoprecipitation (ChIP)}

The chromatin IP assay was performed as described previously [38]. For quantification of the ChIP assay, real-time PCR was performed with SYBR Green dye on an iCycler iQ (Bio-Rad) system. All quantitative PCR signals from the IP samples were normalized to that of the respective input samples. Values shown are means and $\mathrm{SD}$ of the results from $\geq 3$ independent experiments. The anti-p65 antibody (ab7970) for ChIP was obtained from Millipore. Primers used for the TNFAIP3 promoter were 5'-CAGCCCGACCCAGAGAGTCAC-3' and 5'-CGGGCTCCAAGCTCGCTT-3'. 


\section{Statistical analysis}

Data are presented as mean $\pm \mathrm{SD}$ of at least three independent experiments for each group. A chi-squared exact test and Spearman's correlation were applied to analyze the association between CTCF expression and various clinicopathological parameters. Differences were compared using two-sample $t$-tests or analysis of variance (ANOVA) for independent samples. For all analyses, a value of $P<0.05$ was defined as statistically significant.

\section{Authors' contributions}

J.W. and P.-C.L. performed most of the experiments and participated in data interpretation and manuscript preparation. J.-Y.P. participated in the preparation of the tissue sections and analysis of the immunohistochemistry results. G.-Y.L., J.-Y.L., and X.-M.X. participated in the plasmid construction, cell culture, real-time RT-PCR, and the western blotting assay. J.-H.H. and X.-Z.G. assisted in the collection of patient specimens and information. L.Q. conceived the study, carried out the experimental design and data interpretation, and prepared and revised the manuscript.

\section{ACKNOWLEDGMENTS}

The authors thank Hui-na Zhang for kindly providing the NF-kB reporter plasmid, and Zhi-guo Zhao for his kind help in the analysis of the microarray results.

\section{CONFLICTS OF INTEREST}

The authors declare no competing financial interests.

\section{FUNDING}

This work is supported by the National Natural Science Foundation of China (81301508).

\section{REFERENCES}

1. Chen W, Zheng R, Baade PD, Zhang S, Zeng H, Bray F, Jemal A, Yu XQ, He J. Cancer statistics in China, 2015. CA Cancer J Clin. 2016; 66:115-132.

2. Siegel RL, Miller KD, Jemal A. Cancer statistics, 2016. CA Cancer J Clin. 2016; 66:7-30.

3. Miller KD, Siegel RL, Lin CC, Mariotto AB, Kramer JL, Rowland JH, Stein KD, Alteri R, Jemal A. Cancer treatment and survivorship statistics, 2016. CA Cancer J Clin. 2016; 66:271-289.

4. Ferlay J, Soerjomataram I, Dikshit R, Eser S, Mathers C, Rebelo M, Parkin DM, Forman D, Bray F. Cancer incidence and mortality worldwide: sources, methods and major patterns in GLOBOCAN 2012. Int J Cancer. 2015; 136:E359-386.
5. Ruland J. Return to homeostasis: downregulation of NFkappaB responses. Nat Immunol. 2011; 12:709-714.

6. Chaturvedi MM, Sung B, Yadav VR, Kannappan R, Aggarwal BB. NF-kappaB addiction and its role in cancer: 'one size does not fit all'. Oncogene. 2011; 30:1615-1630.

7. Gilmore TD. Introduction to NF-kappaB: players, pathways, perspectives. Oncogene. 2006; 25:6680-6684.

8. Naugler WE, Karin M. NF-kappaB and cancer-identifying targets and mechanisms. Curr Opin Genet Dev. 2008; 18:19-26.

9. Hirsch HA, Iliopoulos D, Joshi A, Zhang Y, Jaeger SA, Bulyk M, Tsichlis PN, Shirley Liu X, Struhl K. A transcriptional signature and common gene networks link cancer with lipid metabolism and diverse human diseases. Cancer Cell. 2010; 17:348-361.

10. Huber MA, Azoitei N, Baumann B, Grunert S, Sommer A, Pehamberger H, Kraut N, Beug H, Wirth T. NF-kappaB is essential for epithelial-mesenchymal transition and metastasis in a model of breast cancer progression. J Clin Invest. 2004; 114:569-581.

11. Liu B, Sun L, Liu Q, Gong C, Yao Y, Lv X, Lin L, Yao H, Su F, Li D, Zeng M, Song E. A cytoplasmic NFkappaB interacting long noncoding RNA blocks IkappaB phosphorylation and suppresses breast cancer metastasis. Cancer Cell. 2015; 27:370-381.

12. Lobanenkov VV, Nicolas RH, Adler VV, Paterson H, Klenova EM, Polotskaja AV, Goodwin GH. A novel sequence-specific DNA binding protein which interacts with three regularly spaced direct repeats of the CCCTC-motif in the 5'-flanking sequence of the chicken c-myc gene. Oncogene. 1990; 5:1743-1753.

13. Witcher M, Emerson BM. Epigenetic silencing of the p16(INK4a) tumor suppressor is associated with loss of CTCF binding and a chromatin boundary. Mol Cell. 2009; 34:271-284.

14. Soto-Reyes E, Recillas-Targa F. Epigenetic regulation of the human $\mathrm{p} 53$ gene promoter by the CTCF transcription factor in transformed cell lines. Oncogene. 2010; 29:2217-2227.

15. Mendez-Catala CF, Gretton S, Vostrov A, Pugacheva E, Farrar D, Ito Y, Docquier F, Kita GX, Murrell A, Lobanenkov V, Klenova E. A novel mechanism for CTCF in the epigenetic regulation of Bax in breast cancer cells. Neoplasia. 2013; 15:898-912.

16. Kim TH, Abdullaev ZK, Smith AD, Ching KA, Loukinov DI, Green RD, Zhang MQ, Lobanenkov VV, Ren B. Analysis of the vertebrate insulator protein CTCF-binding sites in the human genome. Cell. 2007; 128:1231-1245.

17. Cuddapah S, Jothi R, Schones DE, Roh TY, Cui K, Zhao K. Global analysis of the insulator binding protein CTCF in chromatin barrier regions reveals demarcation of active and repressive domains. Genome Res. 2009; 19:24-32.

18. Filippova GN, Lindblom A, Meincke LJ, Klenova EM, Neiman PE, Collins SJ, Doggett NA, Lobanenkov VV. A widely expressed transcription factor with multiple DNA 
sequence specificity, CTCF, is localized at chromosome segment 16q22.1 within one of the smallest regions of overlap for common deletions in breast and prostate cancers. Genes Chromosomes Cancer. 1998; 22:26-36.

19. Tiffen JC, Bailey CG, Marshall AD, Metierre C, Feng Y, Wang Q, Watson SL, Holst J, Rasko JE. The cancer-testis antigen BORIS phenocopies the tumor suppressor CTCF in normal and neoplastic cells. Int J Cancer. 2013; 133:1603-1613.

20. Yoshida K, Toki T, Okuno Y, Kanezaki R, Shiraishi Y, SatoOtsubo A, Sanada M, Park MJ, Terui K, Suzuki H, Kon A, Nagata Y, Sato Y, et al. The landscape of somatic mutations in Down syndrome-related myeloid disorders. Nat Genet. 2013; 45:1293-1299.

21. Filippova GN, Qi CF, Ulmer JE, Moore JM, Ward MD, Hu YJ, Loukinov DI, Pugacheva EM, Klenova EM, Grundy PE, Feinberg AP, Cleton-Jansen AM, Moerland EW, et al. Tumor-associated zinc finger mutations in the CTCF transcription factor selectively alter tts DNA-binding specificity. Cancer Res. 2002; 62:48-52.

22. Kandoth C, Schultz N, Cherniack AD, Akbani R, Liu Y, Shen H, Robertson AG, Pashtan I, Shen R, Benz CC, Yau C, Laird PW, Ding L, et al, and Cancer Genome Atlas Research Network. Integrated genomic characterization of endometrial carcinoma. Nature. 2013; 497:67-73.

23. Aulmann S, Blaker H, Penzel R, Rieker RJ, Otto HF, Sinn HP. CTCF gene mutations in invasive ductal breast cancer. Breast Cancer Res Treat. 2003; 80:347-352.

24. Rasko JE, Klenova EM, Leon J, Filippova GN, Loukinov DI, Vatolin S, Robinson AF, Hu YJ, Ulmer J, Ward MD, Pugacheva EM, Neiman PE, Morse HC 3rd, et al. Cell growth inhibition by the multifunctional multivalent zincfinger factor CTCF. Cancer Res. 2001; 61:6002-6007.

25. Green AR, Krivinskas S, Young P, Rakha EA, Paish EC, Powe DG, Ellis IO. Loss of expression of chromosome 16q genes DPEP1 and CTCF in lobular carcinoma in situ of the breast. Breast Cancer Res Treat. 2009; 113:59-66.

26. Torrano V, Chernukhin I, Docquier F, D'Arcy V, Leon J, Klenova E, Delgado MD. CTCF regulates growth and erythroid differentiation of human myeloid leukemia cells. J Biol Chem. 2005; 280:28152-28161.

27. Zhao X, Li D, Pu J, Mei H, Yang D, Xiang X, Qu H, Huang K, Zheng L, Tong Q. CTCF cooperates with noncoding RNA MYCNOS to promote neuroblastoma progression through facilitating $\mathrm{MYCN}$ expression. Oncogene. 2016; 35:3565-3576.

28. Biswas DK, Iglehart JD. Linkage between EGFR family receptors and nuclear factor kappaB (NF-kappaB) signaling in breast cancer. J Cell Physiol. 2006; 209:645-652.
29. Park BK, Zhang H, Zeng Q, Dai J, Keller ET, Giordano T, Gu K, Shah V, Pei L, Zarbo RJ, McCauley L, Shi S, Chen S, et al. NF-kappaB in breast cancer cells promotes osteolytic bone metastasis by inducing osteoclastogenesis via GMCSF. Nat Med. 2007; 13:62-69.

30. O'Shea JM, Perkins ND. Regulation of the RelA (p65) transactivation domain. Biochem Soc Trans. 2008; 36:603-608.

31. Wang L, Wu X, Shi T, Lu L. Epidermal growth factor (EGF)induced corneal epithelial wound healing through nuclear factor kappaB subtype-regulated CCCTC binding factor (CTCF) activation. J Biol Chem. 2013; 288:24363-24371.

32. Zhang H, Zhu L, He H, Zhu S, Zhang W, Liu X, Zhao X, Gao C, Mei M, Bao S, Zheng H. NF-kappa B mediated up-regulation of CCCTC-binding factor in pediatric acute lymphoblastic leukemia. Mol Cancer. 2014; 13:5.

33. Vendrell JA, Ghayad S, Ben-Larbi S, Dumontet C, Mechti N, Cohen PA. A20/TNFAIP3, a new estrogenregulated gene that confers tamoxifen resistance in breast cancer cells. Oncogene. 2007; 26:4656-4667.

34. Mitchell A, Dass CR, Sun LQ, Khachigian LM. Inhibition of human breast carcinoma proliferation, migration, chemoinvasion and solid tumour growth by DNAzymes targeting the zinc finger transcription factor EGR-1. Nucleic Acids Res. 2004; 32:3065-3069.

35. Fahmy RG, Dass CR, Sun LQ, Chesterman CN, Khachigian LM. Transcription factor Egr-1 supports FGFdependent angiogenesis during neovascularization and tumor growth. Nat Med. 2003; 9:1026-1032.

36. Li D, Ilnytskyy Y, Kovalchuk A, Khachigian LM, Bronson RT, Wang B, Kovalchuk O. Crucial role for early growth response-1 in the transcriptional regulation of miR$20 \mathrm{~b}$ in breast cancer. Oncotarget. 2013; 4:1373-1387. doi: 10.18632/oncotarget.1165.

37. Tront JS, Huang Y, Fornace AJ Jr, Hoffman B, Liebermann DA. Gadd45a functions as a promoter or suppressor of breast cancer dependent on the oncogenic stress. Cancer Res. 2010; 70:9671-9681.

38. Wu J, Zhou LQ, Yu W, Zhao ZG, Xie XM, Wang WT, Xiong J, Li M, Xue Z, Wang X, Zhang P, Mao BB, Hao DL, et al. PML4 facilitates erythroid differentiation by enhancing the transcriptional activity of GATA-1. Blood. 2014; 123:261-270.

39. Zhou LQ, Wu J, Wang WT, Yu W, Zhao GN, Zhang P, Xiong J, Li M, Xue Z, Wang X, Xie XM, Guo ZC, Lv X, et al. The AT-rich DNA-binding protein SATB2 promotes expression and physical association of human (G) gamma- and (A)gamma-globin genes. J Biol Chem. 2012; 287:30641-30652. 